\title{
MODELING PROCESS OF WATER BUBBLING WITH OZONE TO OBTAIN DISINFECTANT SOLUTIONS IN BEEKEEPING
}

\author{
Sergei Oskin, Dmitry Tsokur, Sergey Voloshin \\ Kuban State Agrarian University, Russia \\ mechanization@kubsau.ru,dmitry_tsokur@mail.ru, luntik-s@mail.ru
}

\begin{abstract}
Disinfection of beehives and beekeeping equipment plays an important role in beekeeping. How it will be produced influences not only the health of the bee family, but also the productivity of the apiary. In this case, the use of environmentally friendly methods of obtaining disinfectant solutions is most important. In our opinion, one of these methods is the method of obtaining disinfecting aqueous solutions of ozone by bubbling. Ozone is a strong oxidizer, even greater than oxygen. Ozone has a disinfecting effect and unlike chlorine does not form toxins. Ozone-air mixture has been successfully used for the prevention and treatment of bacteriosis of bees. The use of ozone to produce disinfectant solutions will further expand the scope of its application in the apiary. It is first necessary to simulate the process of bubbling water with ozone in order to justify the parameters and modes of operation of the installation for production of disinfecting aqueous solutions of ozone. The simulation of this process is made in the program Comsol Multiphysics 5.4. In this program the $2 \mathrm{D}$ model of the installation was created and the physical modules responsible for modeling the motion of gas bubbles in liquid were configured, as well as with regard of the chemical reactions occurring in water during ozone bubbling. The simulation results can justify the bubbling parameters: concentration of ozone at the entrance to the setting and time of receiving of the solution. It is proposed to conduct its electric activation in the diaphragm of the electrolyzer before bubbling with ozone to enhance the action of the disinfectant solution. The purpose of this research is to develop a model of the process of water bubbling with ozone, which substantiates the time of bubbling sufficient to obtain a disinfectant solution used in disinfection of bee hives.
\end{abstract}

Keywords: ozone, beekeeping, disinfectant solutions, modeling.

\section{Introduction}

Disinfection of beehives and all other beekeeping equipment is one of the most important activities carried out by a beekeeper at the apiary. Not only the health of the bee colonies, the marketable amount of the bee products, but also the survival of bees directly depend on the proper processing of bee housing during the season. So, the experienced beekeepers spare neither time nor money for disinfection of bee equipment. To carry out this technological operation, we propose to use water bubbled with ozone $\mathrm{O}_{3}$ as a means of reducing the seeding with pathogenic microorganisms. Ozone itself is a strong disinfectant and is able to kill even viruses. When bubbling water with this gas, additional oxidizers are formed in the water such as oxygen $\mathrm{O}_{2}$, hydroperoxyl radical $\mathrm{HO}_{2}$, hydrogen peroxide $\mathrm{H}_{2} \mathrm{O}_{2}$, which increase the disinfecting properties of the resulting solution. Currently, water bubbling with ozone is widely used in medicine for preparation of physiological solutions, for wastewater treatment [1-3]. Despite this, the parameters of the process of water bubbling with ozone to produce disinfectant solutions have not yet been determined. In order to recommend the most optimal parameters of water bubbling with ozone it is necessary to carry out mathematical modeling of this process. Thus, the purpose of this research is to develop a model of the process of water bubbling with ozone, which substantiates the time of bubbling sufficient to obtain a disinfectant solution used in disinfection of bee hives.

\section{Materials and methods}

At present there are two generally accepted models of ozone decomposition: SBH and TFG. According to [4], the former is the appropriate one. We present some chemical reactions from the SBH model that are directly related to ozone decomposition:

$$
\begin{gathered}
\mathrm{O}_{3}+\mathrm{OH} \rightarrow \mathrm{HO}_{2}+\mathrm{O}_{2} \\
\mathrm{O}_{3}+\mathrm{H} \rightarrow \mathrm{HO}_{3} \\
\mathrm{O}_{3}+\mathrm{OH} \rightarrow \mathrm{HO}_{4} \\
\mathrm{O}_{3}+\mathrm{H}_{2} \mathrm{O} \rightarrow \mathrm{HO}_{3}+\mathrm{OH}
\end{gathered}
$$


The production of hydrogen peroxide $\mathrm{H}_{2} \mathrm{O}_{2}$ is also worth mentioning:

$$
\mathrm{HO}_{2}+\mathrm{H} \rightarrow \mathrm{H}_{2} \mathrm{O}_{2}
$$

These are not all reactions of ozone decomposition in water, but they can give a picture of what is happening and what compounds are obtained.

The following assumptions are made to model ozone bubbling:

- density of gas is negligible compared to the density of liquid;

- movement of gas bubbles relative to the liquid is determined by the balance between the forces of viscous resistance and pressure;

- liquid and gas phases having the same pressure field;

- volume fraction of gas does not exceed $10 \%$;

- diameter of the gas bubbles from 1 to $2 \mathrm{~mm}$.

In general, with regard to the assumptions made, the system of equations for the process under consideration will be [5]:

$$
\begin{gathered}
\phi_{l} \rho_{l} \frac{\partial u_{l}}{\partial t}+\phi_{1} \rho_{l} u_{l} \cdot \nabla u_{l}=-\nabla p+\nabla \cdot\left(\phi_{l}\left(\mu_{l}+\mu_{T}\right)\left(\nabla u_{l}+\nabla u_{l}^{T}\right)\right)+\phi_{l} \rho_{l} g+F \\
\rho_{l} \nabla \cdot u_{l}=0
\end{gathered}
$$

where $u_{l}$ - velocity vector for water, $\mathrm{m} \cdot \mathrm{s}^{-1}$;

$p$ - pressure, $\mathrm{Pa}$;

$\phi_{1}-$ volume fraction of water, $\mathrm{m}^{3} \cdot \mathrm{m}^{-3}$;

$\rho_{l}$ - the density of water, $\mathrm{kg} \cdot \mathrm{m}^{-3}$;

$g$ - gravity vector, $\mathrm{m} \cdot \mathrm{s}^{-2}$;

$F-$ any additional volume force, $\mathrm{N} \cdot \mathrm{m}^{-3}$;

$\mu_{l}$ - dynamic viscosity of water, $\mathrm{Pa} \cdot \mathrm{s}$;

$\mu_{T}-$ turbulent viscosity, $\mathrm{Pa} \cdot \mathrm{s}$.

In our case, the dynamic viscosity $\mu_{T}$ is absent. Velocity of gas $u_{g}$ is a total of the velocity of the liquid phase $u_{l}$ and the velocity between the phases $u_{\text {slip }}$ :

$$
u_{g}=u_{l}+u_{s l i p}
$$
[6]:

The balance between the viscous drag force, $f_{D}$ and the pressure gradient is used as a slip model

$$
\begin{gathered}
\phi_{g} \nabla p=f_{D} \\
f_{D}=-\phi_{d} C_{d} \frac{3}{4} \frac{\rho_{l}}{d_{b}}\left|u_{s l i p}\right| u_{s l i p}
\end{gathered}
$$

where $d_{b}$ - bubble diameter, $\mathrm{m}$;

$C_{d}-$ viscous drag coefficient.

Since we have assumed that the diameter of the gas bubbles will be in the range from 1 to $2 \mathrm{~mm}$, we can use the model of Hadamard-Rybczynski to determine $C_{d}$ [7]:

$$
C_{d}=\frac{16}{\operatorname{Re}_{b}}, \quad \operatorname{Re}_{b}=\frac{d_{b} \rho_{l}\left|u_{s l i p}\right|}{\mu_{l}}
$$

Mass exchange between liquid and gas is calculated on two-film theory:

$$
m_{g l}=N M a
$$

where $m_{g l}-$ mass transfer from gas to liquid, $\mathrm{kg} \cdot\left(\mathrm{m}^{3} \cdot \mathrm{c}\right)^{-1}$;

$N$ - Henry's constant, $\mathrm{mol} \cdot\left(\mathrm{s} \cdot \mathrm{m}^{2}\right)^{-1}$;

$a-$ interfacial surface area per unit of volume, $\mathrm{m}^{2} \cdot \mathrm{m}^{-3}$; 
$M$ - molecular mass of ozone, $\mathrm{kg} \cdot \mathrm{mol}^{-1}$.

The Henry's constant can be found by the formula:

$$
N=k\left(c^{*}-c\right)
$$

where $k$-mass transfer coefficient, $\mathrm{m} \cdot \mathrm{s}^{-1}$;

$c$ - dissolved gas concentration in liquid, $\mathrm{mol} \cdot \mathrm{m}^{-3}$;

$c^{*}$ - equilibrium concentration of gas dissolved in liquid, $\mathrm{mol} \cdot \mathrm{m}^{-3}$;

$$
c^{*}=\frac{p+p_{r e f}}{H}
$$

where $p_{\text {ref }}-$ reference pressure, Pa;

$H$ - Henry constant, $\left(\mathrm{Pa}^{3} \mathrm{~m}^{3}\right) \cdot \mathrm{mol}^{-1}$.

The coefficient of mass exchange $k$ and the Henry's constant were found in scientific literature and are equal to $2.5 \cdot 10^{-3} \mathrm{~m} \cdot \mathrm{s}^{-1}$ and $0.220 \mathrm{kPa} \cdot \mathrm{L} \cdot \mathrm{m}^{-1}$ respectively [8].

The modeling was made in the program Comsol Multiphysics 5.4. There were used 2 physical modules: Bubble Flow and Transport of Diluted Species. The obtained model is similar to the model of water bubbled with carbon dioxide, this process was described in detail in [9]. The general view of the geometric model is shown in Fig. 1.

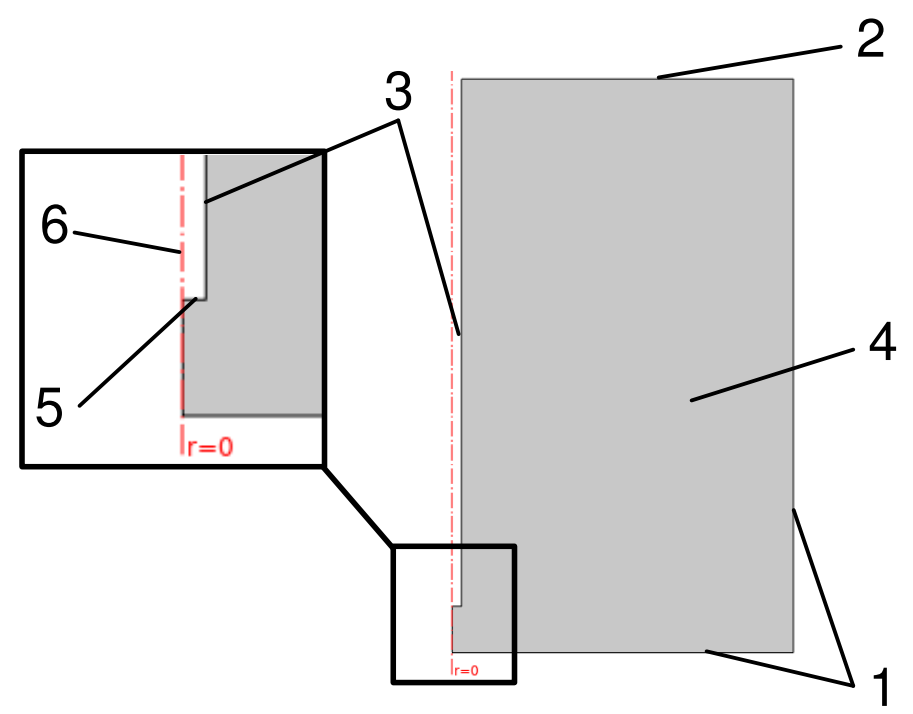

Fig. 1. Geometric model of ozone bubbled water: 1 - wall; 2 - ozone outlet; 3 - ozone supply tube; 4 - water; 5 - ozone inlet; 6 - axis of symmetry

For water bubbling with ozone it is advisable to use the same ozonizers that are used for the prevention and treatment of bee diseases. The concentration of the ozone - air mixture in the hive, which is supplied by such ozonizers, is $50 \mathrm{mg} \cdot \mathrm{m}^{-3}$ [10]. The ozone concentration entering the liquid is the same. The hole of the ozone supply tube has a diameter of $4 \mathrm{~mm}$. The bubbling time is 100 seconds. The tank for bubbling is a cylinder with a diameter of $15 \mathrm{~cm}$ and a height of $12.5 \mathrm{~cm}$.

\section{Results and discussion}

The graph of the change of the mean ozone concentration over time is presented in Fig. 2 during the modeling. The ozone concentration fields were obtained at different time intervals, some of them were shown in Fig. 3.

It can be concluded from Figure 2 that the concentration of ozone in water will be above $0.001 \mathrm{~mol} \cdot \mathrm{m}^{-3}\left(50 \mathrm{mg} \cdot \mathrm{m}^{-3}\right)$ after 50 seconds, and it is sufficient for treatment and disinfection of beehives by spraying them with the obtained solution [10]. 


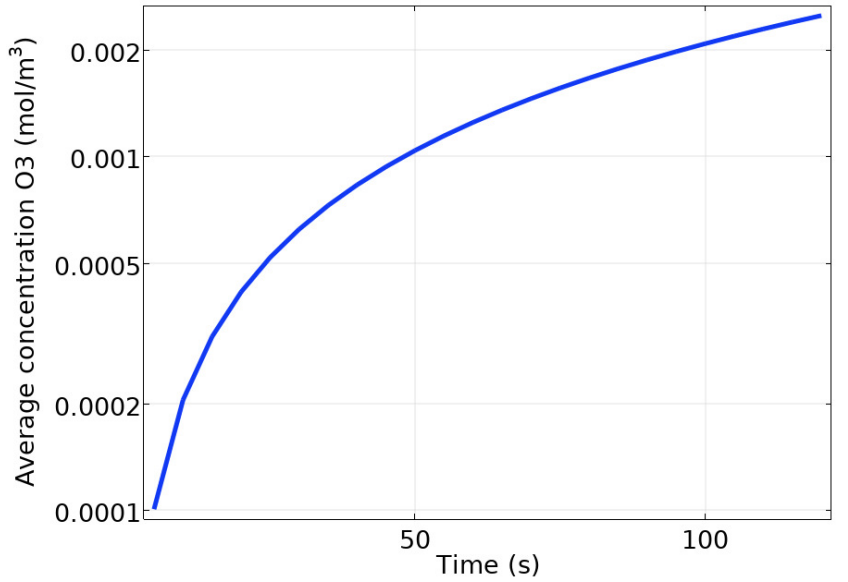

Fig. 2. Change of mean ozone concentration over time
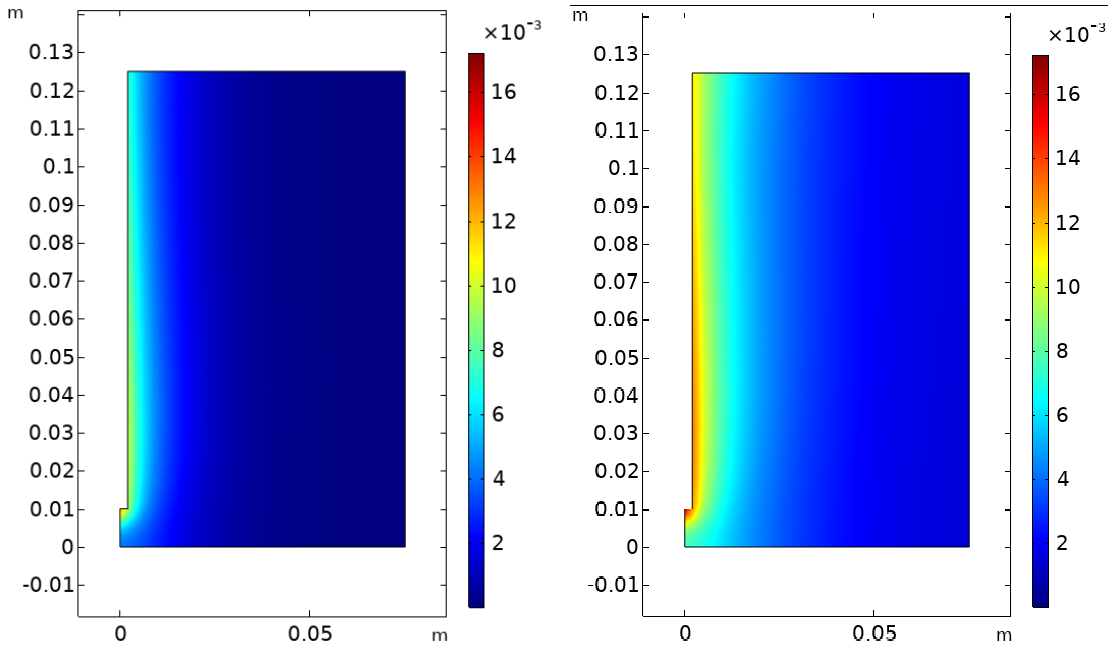

Fig. 3. Ozone concentration fields after 20 seconds (left) and after 120 seconds (right)

The fields of liquid phase velocities due to convective transport of dissolved ozone during the simulation were obtained, which are shown in Fig. 4.
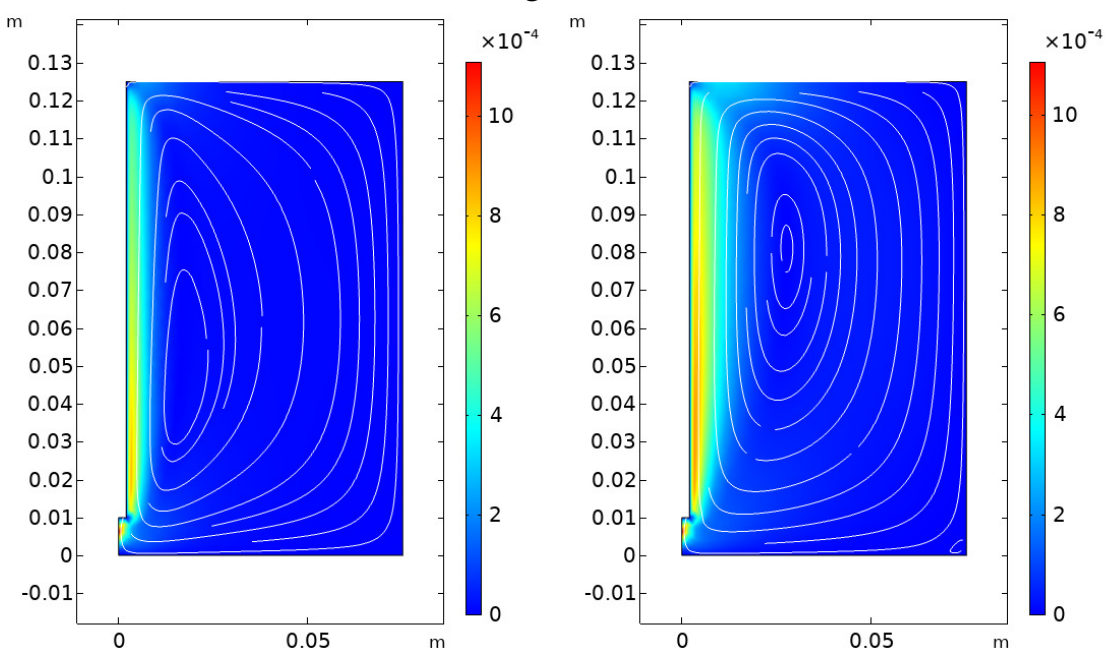

Fig. 4. Liquid phase velocity fields after 20 seconds (left) and after 120 seconds (right)

Since after termination of the bubbling process the ozone concentration in the water will be reduced due to the interaction of ozone with water molecules and hydroxyl ions, it is proposed to increase the bubbling time to 120 seconds to have time to pour the solution into the sprayer and treat the hive. 
In 2017 the patent was obtained using such diaphragm in the electric activator [11].

\section{Conclusions}

Thus, it is possible to recommend the following parameters for experimental studies on the effect of the solution bubbled with ozone on the bacterial contamination of sprayed hives and bee equipment:

- concentration of ozone at the entrance to water is $50 \mathrm{mg} \cdot \mathrm{m}^{-3}$;

- time of barbotage for 2 minutes.

In our opinion, the process of bubbling of water with ozone and saturation of water with such oxidants as $\mathrm{O}_{2}, \mathrm{HO}_{2}$ and $\mathrm{H}_{2} \mathrm{O}_{2}$ can be combined with the process of water electrolysis in the diaphragm electric activator. This can be achieved by replacing the diaphragm of the electric activator with the flow of ozone bubbles between the anode and the cathode. This will reduce the time to obtain the disinfectant solution, as well as increase the operational properties of the electric activator due to the lack of the diaphragm and inabilities to clog its pores with salts. In 2017 the patent was obtained using such diaphragm in the electric activator. Our further researches will be directed to the research and improvement of such installations.

\section{References}

[1] Peretyagin S. P., Kuvakina N. A., Peretyagina N. S., Kolesina N. V., Struchkov A. A. Sposob ozonirovaniya fiziologicheskogo rastvora [Method of ozonation of saline solution]. Patent Russia, no. 2289413. 2004.

[2] Bhatta R., Kayastha R., Subedi D.P., Joshi R. "Treatment of Wastewater by Ozone Produced in Dielectric Barrier Discharge," Journal of Chemistry, vol. 2015, Article ID 648162, 6 pages, 2015. https://doi.org/10.1155/2015/648162.

[3] Usupaev A.M. Application of ozone for post-treatment of industrial wastewater treated with biological treatment. Molodoj uchenyj, 2017, no. 23.2, pp. 14-16 (In Russian).

[4] Morozov P.A. Zakonomernosti razlozheniya ozona v vode i v vod nyh rastvorah. Optimizaciya okislitel'nyh processov. Diss. kand. tehn. nauk [Regularities of ozone decomposition in water and in aqueous solutions. Optimization of oxidation processes. PhD thesis]. Moscow, Institute of Physical Chemistry and Electric Chemistry named after A.N. Frumkin, 2009. 127 p. (In Russian).

[5] CFD Module User's Guide. COMSOL.

[6] Kuzmin D., Turek S., Haario H. Finite Element Simulation of Turbulent Bubbly Flows in Gasliquid Reactors, Ergebnisberichte Angew, Math, 298, University of Dortmund, 2005.

[7] Crowe C., Sommerfeld M., Tsuji Y., Multiphase Flows with Droplets and Particles, CRC Press, 1998.

[8] Zhou H., Smith D.W., Stanley S.J. Modeling of dissolved ozone concentration profiles in bubble columns. Journal of Environmental Engineering, Vol. 120, No. 4, July/August, 1994 - p 821-840.

[9] Tholeti S.S. Modeling of bubbling process in COMSOL. Comsol blog. [online][16.02.2019] Available at: https://www.comsol.ru/blogs/how-to-model-sparging-in-comsol-multiphysics.

[10] Nikolaenko S.A. Parametry sistemy stabilizirovannogo ehlektroozonirovaniya ul'ev pri lechenii bakteriozov pchel [Parameters of the system of stabilized electric ozonization of beehives at the treatment of bee bacteriosis. PhD thesis]. Krasnodar, Kuban State Agrarian University, 2010. 175 p. (In Russian).

[11] Oskin S.V., Tsokur D.S. Elektroaktivator vody [Electric activator of water]. Patent of Russia, no. 2663153. 2017. 